\title{
Formulation and evaluation of a bilayer tablet comprising of diclofenac potassium as orodispersible layer and diclofenac sodium as sustained release core
}

Jabbar Abbas, Sajid Bashir, Muhammad Samie, Sadaf Laghari, Nargis Aman, Habib Ullah Jan, Imran Nazir

\begin{abstract}
Diclofenac a phenylacetic acid derivative has long been used as an anti-inflammatory and analgesic drug to treat certain conditions however its sustained release formulation with immediate release loading dose is desirable. The rationale of the current work was to develop and evaluate bilayer tablets with diclofenac potassium as orodispersible layer and diclofenac sodium as sustained release core. The diclofenac sodium core was prepared by wet granulation method while the orodispersible outer layer was prepared by direct compression method using super disintegrant sodium starch glycolate. The powder blends were then evaluated for both pre-compressional and post compressional properties. The physical parameters
\end{abstract}

of both powders and tablets were in accordance with the compendial standards. The orodispersible portion disintegrated in less than $30 \mathrm{sec}$ releasing diclofenac potassium as the loading dose while the core was able to sustain the release of diclofenac sodium up to $10 \mathrm{hrs}$ in simulated intestinal fluid ( $\mathrm{pH} \mathrm{6.8).} \mathrm{The}$ kinetic data revealed that the release pattern was best fitted into Korsmeyer-Peppas model with non-fickian release. The outer orodispersible layer of diclofenac potassium and sustained release inner core of diclofenac sodium in a single tablet was successfully formulated while sodium starch glycolate showed to have good super disintegrant properties.

Keywords: Orodispersible, Sustained release, Diclofenac, Direct Compression, Bilayer tablet.
Jabbar Abbas

Institute of Pharmaceutical Sciences, People's University of medical and health sciences for women, Shaheed Benazir Abad 67450 Pakistan.

Sajid Bashir

Faculty of Pharmacy, University of Sargodha, Sargodha 40100 Pakistan.

Muhammad Samie, Nargis Aman, Imran Nazir

Department of Pharmacy, Comsats institute of information technology, Abbottabad 22060 Pakistan.

Sadaf Laghari

College of Pharmacy, Liaqat University of Medical \& Health Sciences, Jamshoro 76090 Pakistan.

Habib Ullah Jan

Department of Pharmacy, Abdul Wali Khan University, Mardan 23200 Pakistan.

Corresponding Author:

Muhammad Samie

e-mail:sami.jadoon.83@gmail.com,samijadoon@ciit.net.pk

Submitted / Gönderilme: 06.02.2017

Revised / Düzeltme: 03.04.2017

Accepted / Kabul: $\quad 05.04 .2017$

\section{INTRODUCTION}

The increased costs in the discovery of new drug molecules has turned the focus of researchers to formulate dosage forms with altered release mechanisms (1). Oral route is the most ancient and well acknowledged route of drug administration and has been used for both conventional and novel drug delivery systems due to its cost effectiveness, ease in drug administration and improved patient compliance. In the past few years modified release dosage forms have limited the use of conventional dosage forms to a larger extent due to reduction in dosage frequency and improved patient compliance (2). The oral route on the other hand has some limitations like first pass metabolism and degradation of the drug in the presence of gastrointestinal enzymes which confines the administration of certain classes of drugs like proteins and peptides through this route. This route is also non-suitable in conditions when quick onset of action is required (3). To overcome this problem, the other absorptive mucosal barriers that are involved in the absorption like 
ocular, nasal, oral, vaginal and rectal are being considered as potential sites for drug absorption.

Orodispersible dosage forms are an emerging class of medicines and a new drug delivery system. When these dosage forms are placed on tongue the saliva disintegrates and dissolves them in less than a minute without the need of chewing/water, liberating the drug free for oral absorption (4). Rapid disintegration followed by rapid dissolution and absorption results in quick onset of action (5). Opposing to conventional immediate release dosage forms sustained release matrix tablets assure better patient compliance through reduction in the total dose, which is of great importance when patients are supposed to go through chronic treatment regimen (6). This makes sustained release dosage forms a better alternative especially for drugs which have peak plasma levels linked with adverse effects. Sustained release matrix tablets are formulated mainly by wet granulation, direct compression or solid dispersion method using polymers like poly methyl methacrylate (PMMA), poly glycolic acid (PGA), hydroxypropyl methyl cellulose (HPMC), ethyl cellulose (EC) etc. The retardant materials may be of hydrophilic, hydrophobic, mineral or biodegradable types and aid in controlling the release of drug from the matrix core.

The simplest and common method of prolonging the drug release from an oral dosage form is to incorporate the drug in an inert polymer matrix. In solvent activated drug delivery system the interaction between polymer and water which results in plasticization, erosion, swelling or degradation of polymer is responsible for achieving sustained release. In gelforming hydrophilic matrix systems the drug is dispersed in a swellable hydrophilic polymer. The hydrophilic polymer starts swelling and becomes plasticized due to chain relaxation and resultant volume expansion upon contact with the aqueous gastrointestinal fluids. The release of dissolved drug mainly occurs through diffusion within the swollen gel layer. An attempt has been made recently to formulate domperidone tablets with both orodispersible and sustained release technology holding the convenience of administration, quick clinical response and benefits of controlled release product at the same time. The developed technology provides an easy approach and seeks exploitation for commercial use in future (7). Diclofenac is the most commonly prescribed non-steroidal anti-inflammatory drug (NSAID), that has shown to be useful in the treatment of a variety of painful conditions (8).

The rapid systemic clearance of diclofenac makes it a suitable candidate to be formulated as SR dosage form to prolong drug action, and improve patient compliance and till date few formulations are available as market products (9). Diclofenac almost absorbs completely after oral administration however it is taken up by the hepatic portal system before reaching the systemic circulation and about $50 \%$ of the drug is lost. Polymers play an important role in formulation and are long been used in targeted drug delivery systems because of their unique properties. The drug is homogeneously dispersed in hydrophilic or hydrophobic polymer matrix (10). Hydrophilic polymers hydrate upon contact with water and converts into a gel like structure through which the drug diffuses. To produce action for longer duration it is important that the dosage form should remain intact, stay longer in the stomach or upper part of intestine and the drug is released at a controlled rate (11). Drug release occurs from hydrophilic matrices as a result of multifaceted interaction between the mechanisms of absorption, swelling, dissolution, diffusion and erosion (12). HPMC is a semisynthetic derivative of cellulose and is the first choice to be used for years in hydrophilic matrix systems as swellable hydrophilic controlled release polymer (13). Figure 1 shows the chemical structure of HPMC.

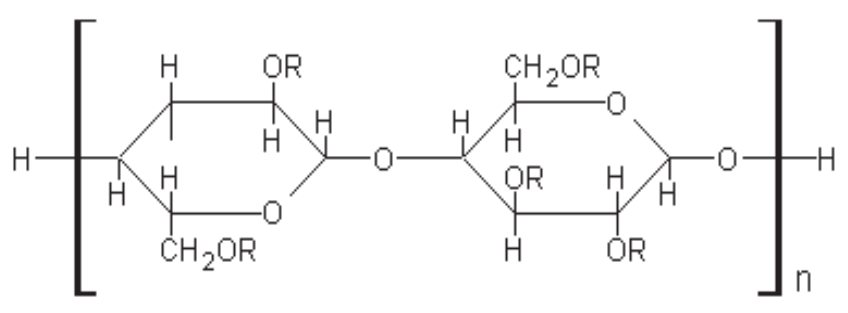

Figure 1. Structure of HPMC

The use of sodium starch glycolate as disintegrant in oral pharmaceuticals has been since long in capsules (14) and tablet formulations (15). It is a commonly employed polymer in tablets manufactured either through directcompression or wet-granulation processes (16). It is usually employed in the concentration between $2 \%$ and $8 \%$ during formulation. Disintegration occurs as a result of rapid uptake of water followed by immediate swelling. The current work is focused on developing of a bilayer tablet containing diclofenac potassium in the outer orodispersible shell and diclofenac sodium as sustained release in the inner core. The objective of the study is to improve therapeutic efficacy by giving quick relief from pain with reduced toxicity. Different drug polymer ratios will be used by employing primogel as super disintegrant and HPMC as release modifying polymer. 


\section{MTERIALS AND METHODS}

\section{CHEMICALS}

Diclofenac sodium and Diclofenac potassium were received as gift samples from Saffron pharma Faisalabad, Pakistan. Lactose, HPMC K-15 and Magnesium stearate were purchased from DMV-Fonterra Germany, Zhongbao chemicals China and Peter Greven Asia Malysia respectively. Primogel (sodium starch glycolate) and Avicel PH-200 (Microcrystalline cellulose) were purchased from Mingtai chemical, Taiwan. All the chemicals and solvents used were of analytical grade

\section{METHOD OF PREPARATION}

\section{Preparation of Matrix Tablet}

Diclofenac sodium, lactose and sufficient amount of HPMC K-15 were all mixed together in horizontal mixer after passing through mesh of sieve size 60 and slowly added purified water until a slightly wet mass is obtained. The damp mass was placed in stainless steel trays inside hot air oven and dried at a temperature of $60^{\circ} \mathrm{C}$. After drying the dried material was passed through mesh of sieve size 30 to obtain granular mass. Add magnesium stearate to the remaining amount of HPMC K-15 and pass through mesh of sieve size 60 to obtain uniform mixing (17). The dried granules are then added with the lubricant mixture and mixed for $5 \mathrm{~min}$. The bulk was then compressed into tablets using ZPW rotary press machine (China) (18). Table 1 indicates the composition of all sustained release formulations of the model drug.

\section{Preparation of Orodispersible layer}

Specified quantities of diclofenac potassium, avicel and primogel were sifted through mesh of sieve size 60 and mixed thoroughly for $15 \mathrm{~min}$ to obtain a uniform blend. The contents were mixed further for $5 \mathrm{~min}$ after the addition of magnesium stearate previously sifted through mesh of sieve size 60. After lubrication (with talcum) the final tablets were compressed in such a way that the first and third hopper contain the powder blend while the second hopper contain diclofenac sodium sustained release tablets as previously described by Gohel et al; 2010 (19). Table 2 indicates the composition of orodispersible formulations of the model drug.

\section{CHARACTERIZATION}

\section{Pre-compression properties of powder blend}

The granules were evaluated for pre-compressional properties like bulk density, tapped density, angle of repose, carr's index and Hausner ratio (20).

\section{Post-compression properties of tablets}

The prepared tablets were characterized after their final compression for weight variation, tensile strength, thickness, friability and assay of active drug contents (20).

Table 1. Composition of various formulations of sustained release core of diclofenac sodium

\begin{tabular}{ccccc}
\hline Formulation & $\begin{array}{c}\text { Diclofenac Sodium } \\
(\mathbf{m g})\end{array}$ & $\begin{array}{c}\text { HPMC K-15 } \\
(\mathbf{m g})\end{array}$ & $\begin{array}{c}\text { Lactose } \\
(\mathbf{m g})\end{array}$ & $\begin{array}{c}\text { Magnesium stearate } \\
(\mathbf{m g})\end{array}$ \\
\hline T-01 & 50.0 & 13.5 & 38.5 & 3.0 \\
T-02 & 50.0 & 11.5 & 38.5 & 5.0 \\
T-03 & 50.0 & 16.0 & 38.0 & 1.0 \\
T-04 & 50.0 & 17.5 & 36.5 & 1.0 \\
\hline
\end{tabular}

Table 2. Composition of various formulations of orodispersible layer of diclofenac potassium

\begin{tabular}{cccccc}
\hline Formulation & $\begin{array}{c}\text { Diclofenac potassium } \\
(\mathbf{m g})\end{array}$ & $\begin{array}{c}\text { Avicel } \\
(\mathbf{m g})\end{array}$ & $\begin{array}{c}\text { Primogel } \\
(\mathbf{m g})\end{array}$ & $\begin{array}{c}\text { Mag. stearate } \\
(\mathbf{m g})\end{array}$ & Talcum $^{\mathbf{m}}$ \\
\hline T-01 & 50.0 & 296.5 & 26.5 & 8.3 & 3.3 \\
T-02 & 50.0 & 308.0 & 20.0 & 2.3 & 4.3 \\
T-03 & 50.0 & 301.5 & 28.5 & 2.3 & 2.3 \\
T-04 & 50.0 & 301.5 & 26.5 & 3.3 & 3.3 \\
\hline
\end{tabular}




\section{In-Vitro Drug Release}

In-vitro drug release studies were performed using USP type-II apparatus. The dissolution study for orodispersible layer was carried out in phosphate buffer $\mathrm{pH} 6.8$ for $2 \mathrm{~min}$ using $900 \mathrm{ml}$ of phosphate buffer placed in each vessel of the apparatus and maintained at a temp of $37 \pm 0.5^{\circ} \mathrm{C}$. Each vessel was added single tablet and the apparatus is allowed to run at a speed of $50 \mathrm{rpm}$. An aliquot of $3 \mathrm{ml}$ was withdrawn at specific time intervals and analyzed by UVvisible spectrophotometer. Similarly, the dissolution study for diclofenac sodium sustained release tablets was carried out initially for $2 \mathrm{hrs}$ in $0.1 \mathrm{~N} \mathrm{HCl}$ and then for eight hours in phosphate buffer $\mathrm{pH} 6.8$ under the same conditions as above. $5 \mathrm{ml}$ aliquot was withdrawn from the dissolution medium at specific time intervals and analyzed by UV-visible spectrophotometer for diclofenac contents at a wavelength of $276 \mathrm{~nm}$. After every withdrawal, $5 \mathrm{ml}$ of freshly prepared pre-warmed dissolution medium was added to the vessel in dissolution apparatus to keep its volume constant. Finally, the amount of percent drug release was determined for all formulations.

\section{Drug Release Kinetics}

Various kinetic models were applied to evaluate the possible drug release mechanism. The kinetic models and their equations are as follows;

$$
\begin{array}{ll}
\text { Zero order rate equation } & \mathrm{Q}=\mathrm{kt} \\
\text { First order rate equation } & \mathrm{In}(100-\mathrm{Q})=\mathrm{In} 100-\mathrm{Kt} \\
\text { Higuchi model equation } & \mathrm{Q}=\mathrm{K} 3 \sqrt{\mathrm{t}} \\
\text { Hixon }- \text { Crowell model } & \mathrm{A}_{0}^{1 / 3}-\mathrm{At}^{1 / 3}=\mathrm{kst} \\
\text { Korsmeyer Peppas Equation } & \mathrm{Mt} / \mathrm{Ma}=\mathrm{Ktn}
\end{array}
$$

\section{RESULTS}

\section{Pre-compression properties of granules and powders}

During evaluation of the flow properties the angle of repose for all formulations of diclofenac sodium as well as diclofenac potassium is below $30^{\circ}$ as presented in Tables 3 and 4 respectively which shows that granules and powders have good flow behavior. The Carr's index values were found to be less than $20 \%$ and $25 \%$ in case of diclofenac sodium and diclofenac potassium respectively. These results were supported by Hausner's ratio which in both cases is less than 1.4. The same behavior was also reported previously by Murtaza et al; 2010 (26).

\section{Post-Compressional properties of tablets}

The results of the post compressional studies found for weight variation $105 \pm 5 \%$ for diclofenac sodium sustained release core and $500 \pm 5 \%$ for final tablet, thickness in the range of $3.20 \mathrm{~mm}-3.30 \mathrm{~mm}$ in case of diclofenac sodium core and $5.60 \mathrm{~mm}-5.71 \mathrm{~mm}$ in case of final tablet, hardness

Table 3. Evaluation of granules of diclofenac sodium sustained release core

\begin{tabular}{cccccc}
\hline \multicolumn{5}{c}{ Diclofenac sodium sustained release } \\
\hline Formulation code & Angle of Repose & Bulk density $(\mathbf{g} / \mathbf{m l})$ & Tapped density $(\mathbf{g} / \mathbf{m l})$ & $\begin{array}{c}\text { Carr's Index } \\
(\%)\end{array}$ & Hausner ratio \\
\hline T-01 & $29.93 \pm 0.18$ & $0.713 \pm 0.02$ & $0.850 \pm 0.001$ & $18.16 \pm 0.02$ & $1.19 \pm 0.02$ \\
T-02 & $29.65 \pm 0.09$ & $0.780 \pm 0.05$ & $0.833 \pm 0.003$ & $16.13 \pm 0.04$ & $1.15 \pm 0.06$ \\
T-03 & $29.30 \pm 0.18$ & $0.731 \pm 0.01$ & $0.879 \pm 0.002$ & $16.20 \pm 0.03$ & $1.18 \pm 0.03$ \\
T-04 & $29.56 \pm 0.18$ & $0.758 \pm 0.04$ & $0.893 \pm 0.006$ & $15.15 \pm 0.06$ & $1.19 \pm 0.01$ \\
\hline
\end{tabular}

All data are reported as mean \pm standard deviation, $n=3$ per experiment

Table 4. Evaluation of granules of diclofenac potassium outer orodispersible layer

\begin{tabular}{cccccc}
\hline \multicolumn{5}{c}{ Diclofenac potassium orodispersible outer layer } \\
\hline Formulation code & Angle of Repose & Bulk density $(\mathbf{g} / \mathbf{m l})$ & Tapped density $(\mathbf{g} / \mathbf{m l})$ & $\begin{array}{c}\text { Carr's Index } \\
(\%)\end{array}$ & Hausner ratio \\
\hline T-01 & $29.31 \pm 0.11$ & $0.399 \pm 0.01$ & $0.530 \pm 0.003$ & $25.38 \pm 0.02$ & $1.336 \pm 0.02$ \\
T-02 & $28.63 \pm 0.09$ & $0.390 \pm 0.01$ & $0.529 \pm 0.005$ & $25.11 \pm 0.04$ & $1.335 \pm 0.06$ \\
T-03 & $26.38 \pm 0.12$ & $0.383 \pm 0.03$ & $0.523 \pm 0.001$ & $26.30 \pm 0.01$ & $1.338 \pm 0.03$ \\
T-04 & $25.56 \pm 0.18$ & $0.403 \pm 0.04$ & $0.538 \pm 0.006$ & $24.99 \pm 0.06$ & $1.333 \pm 0.01$ \\
\hline
\end{tabular}

All data are reported as mean \pm standard deviation, $n=3$ per experiment 
in the range of $2.903 \mathrm{Kg} / \mathrm{cm}^{3}-3.703 \mathrm{Kg} / \mathrm{cm}^{3}$ in both cases, friability less than $1 \%$ in both case and disintegration of the orodispersible coat takes place within 21-30sec for all formulations developed. The cumulative results shown in Tables 5 and 6 indicates that all formulations are within the specified limits according to USP (27). All the results were produced in triplicate.

\section{Pharmaceutical Assay}

The percentage of active drug in each tablet was measured by performing the assay on tablets from each formulation. Tables 5 and 6 shows the respective percent drug contents of both diclofenac sodium and diclofenac potassium which fall in the official limits (27).

\section{In-vitro Dissolution Profile}

Dissolution data presented in Table 7 shows the complete drug release profile with respect to time which revealed that all the formulations impeded the drug release from matrices for initial $02 \mathrm{hrs}$ but as the medium was changed to phosphate buffer the drug release initiated and increases with time as previously observed by Kramar, Turk and Vrečer, 2003 (28). The percent drug release with respect to time is mentioned in table (7). A slight change

Table 5. Physical parameters of diclofenac sodium sustained release tablets

\begin{tabular}{cccccc}
\hline \multicolumn{5}{c}{ Diclofenac sodium sustained release } \\
\hline Formulation code & Average weight $(\mathbf{m g})$ & Thickness $(\mathbf{m m})$ & Hardness $($ Kg) & Friability (\%) & Assay $(\%)$ \\
\hline T-01 & 105.5 & 3.23 & 3.02 & 0.16 & 99.23 \\
T-02 & 104.0 & 3.22 & 3.00 & 0.17 & 98.03 \\
T-03 & 104.5 & 3.20 & 3.20 & 0.13 & 99.91 \\
T-04 & 106.0 & 3.30 & 3.50 & 0.15 & 101.33 \\
\hline
\end{tabular}

All data are reported as mean \pm standard deviation, $n=3$ per experiment

Table 6. Physical parameters for diclofenac potassium orodispersible tablet incorporating diclofenac sodium sustained release tablet.

\begin{tabular}{|c|c|c|c|c|c|c|}
\hline Formulation Code & $\begin{array}{c}\text { Average Weight } \\
(\mathrm{mg})\end{array}$ & Thickness (mm) & Hardness (Kg) & Friability (\%) & $\begin{array}{c}\text { Disintegration } \\
\text { time (sec.) }\end{array}$ & Assay (\%) \\
\hline $\mathrm{T}-01$ & 499.0 & 5.68 & 3.70 & 0.65 & 25.0 & 90.33 \\
\hline T-02 & 502.2 & 5.71 & 3.30 & 0.73 & 30.0 & 91.48 \\
\hline $\mathrm{T}-03$ & 501.0 & 5.70 & 3.70 & 0.71 & 21.0 & 92.01 \\
\hline $\mathrm{T}-04$ & 503.8 & 5.60 & 2.90 & 0.60 & 23.0 & 97.45 \\
\hline
\end{tabular}

All data are reported as mean \pm standard deviation, $\mathrm{n}=3$ per experiment

Table 7. Dissolution profile of diclofenac sodium sustained release

\begin{tabular}{|c|c|c|c|c|c|c|c|}
\hline \multirow{2}{*}{ Formulation } & \multicolumn{7}{|c|}{ Drug Release \% } \\
\hline & $0 \mathrm{hr}$ & $1^{\text {st }} h r$ & $2^{\text {nd }} h r$ & $3^{\text {rd }} h r$ & $4^{\text {th }} \mathrm{hr}$ & $6^{\text {th }} h r$ & $10^{\text {th }} \mathrm{hr}$ \\
\hline $\mathrm{T}-1$ & $0 \%$ & $0 \%$ & $0 \%$ & $15.92 \%$ & $30.81 \%$ & $50.12 \%$ & $65.77 \%$ \\
\hline $\mathrm{T}-2$ & $0 \%$ & $0 \%$ & $0 \%$ & $11.83 \%$ & $25.70 \%$ & $56.44 \%$ & $62.13 \%$ \\
\hline $\mathrm{T}-3$ & $0 \%$ & $0 \%$ & $0 \%$ & $18.01 \%$ & $40.25 \%$ & $61.36 \%$ & $70.11 \%$ \\
\hline T-4 & $0 \%$ & $0 \%$ & $0 \%$ & $21.96 \%$ & $39.84 \%$ & $63.36 \%$ & $76.94 \%$ \\
\hline
\end{tabular}

All data are reported as mean \pm standard deviation, $n=3$ per experiment 
in HPMC concentration among formulations T-01 \& T-04 showed significant differences in drug release behavior from hydrophilic matrices. It was the concentration of HPMC that was principally responsible for controlling drug release from the swollen matrices which means that release of diclofenac sodium was found to be dependent on the concentration of the polymer used.

The cumulative dissolution profiles of all formulations describes a correlation between $\%$ drug release and time as shown in figure (2).

\section{Drug Release kinetics:}

Dissolution data obtained was fitted in to different kinetic models. The values of correlation coefficient for equations are presented in Table 8 .

Figures 3-6 indicates the drug release profile of all formulations following Korsmeyer-Peppas Model.

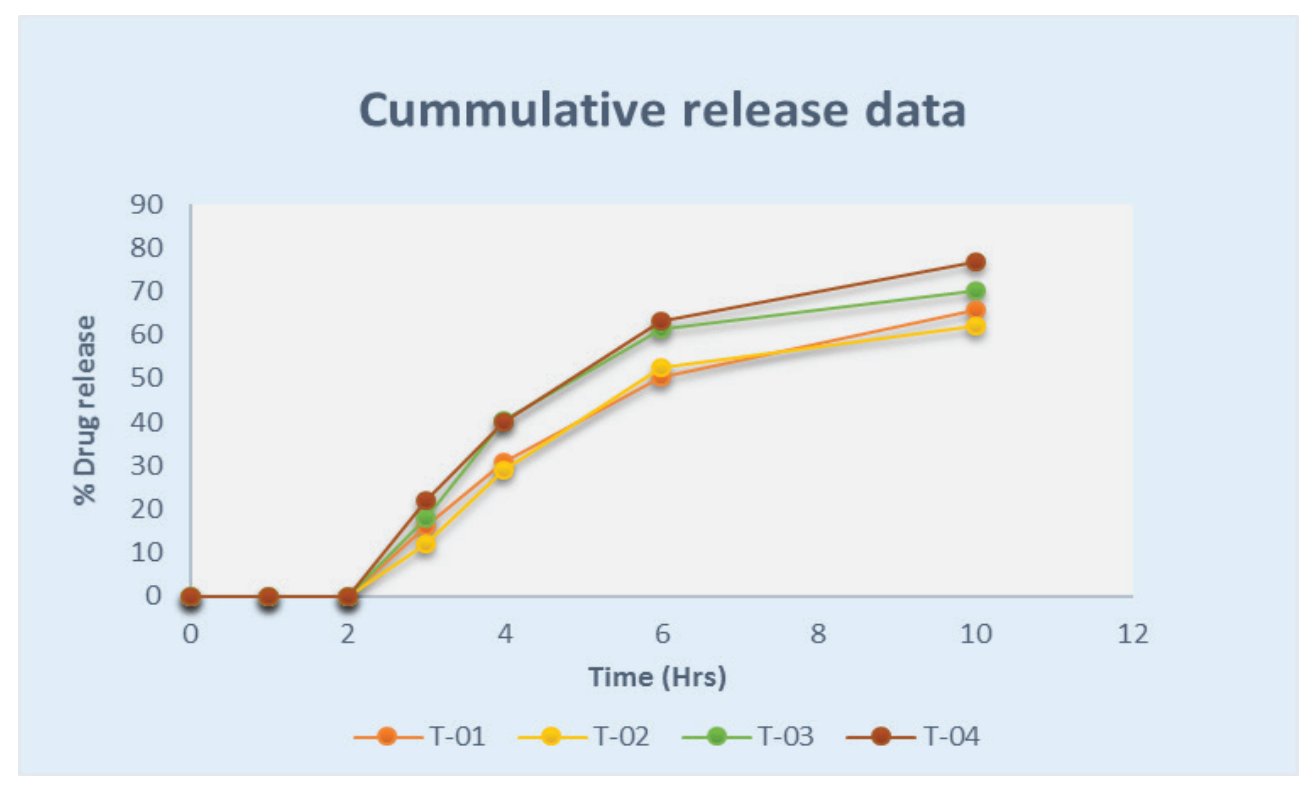

Figure 2 . Drug release profile of all formulations from T-01 - T-04

Table 8. Values of correlation coefficient fitted in to various kinetic models

\begin{tabular}{ccccccccccccc}
\hline Formulation & \multirow{2}{*}{ Zero order Model } & \multicolumn{2}{c}{ First order Model } & \multicolumn{2}{c}{$\begin{array}{c}\text { Higuchi } \\
\text { Model }\end{array}$} & Hixson-Crowell Model & Korsmeyer Peppas Model \\
\hline & $\boldsymbol{k}_{\mathrm{o}}$ & $\boldsymbol{R}^{2}$ & $\boldsymbol{K}_{1}$ & $\boldsymbol{R}^{2}$ & $\boldsymbol{k}_{\mathrm{H}}$ & $\boldsymbol{R}^{2}$ & $\boldsymbol{k}_{\mathrm{HC}}$ & $\boldsymbol{R}^{2}$ & $\boldsymbol{k}_{\mathrm{P}}$ & $\boldsymbol{N}^{2}$ \\
\hline $\mathrm{T}-01$ & 7.567 & 0.932 & 0.119 & 0.959 & 34.23 & 0.954 & 0.461 & 0.700 & 1.940 & 0.864 & 0.993 \\
T-02 & 7.342 & 0.906 & 0.121 & 0.939 & 33.39 & 0.927 & 0.461 & 0.714 & 2.029 & 0.881 & 0.994 \\
T-03 & 8.347 & 0.882 & 0.140 & 0.932 & 37.82 & 0.915 & 0.474 & 0.668 & 2.108 & 0.871 & 0.991 \\
T-04 & 8.989 & 0.909 & 0.165 & 0.953 & 40.62 & 0.939 & 0.485 & 0.672 & 2.155 & 0.881 & 0.994 \\
\hline
\end{tabular}

All data are reported as mean \pm standard deviation, $n=3$ per experiment 


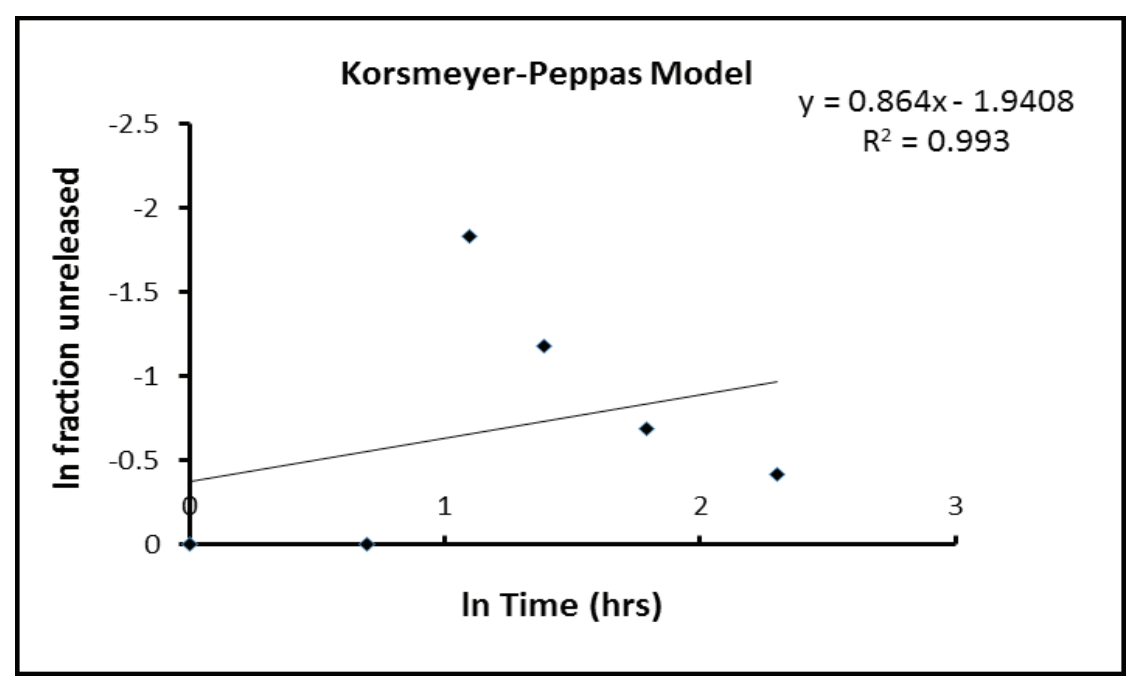

Figure 3. Graph of Korsmeyer-Peppas Model for formulation T-01

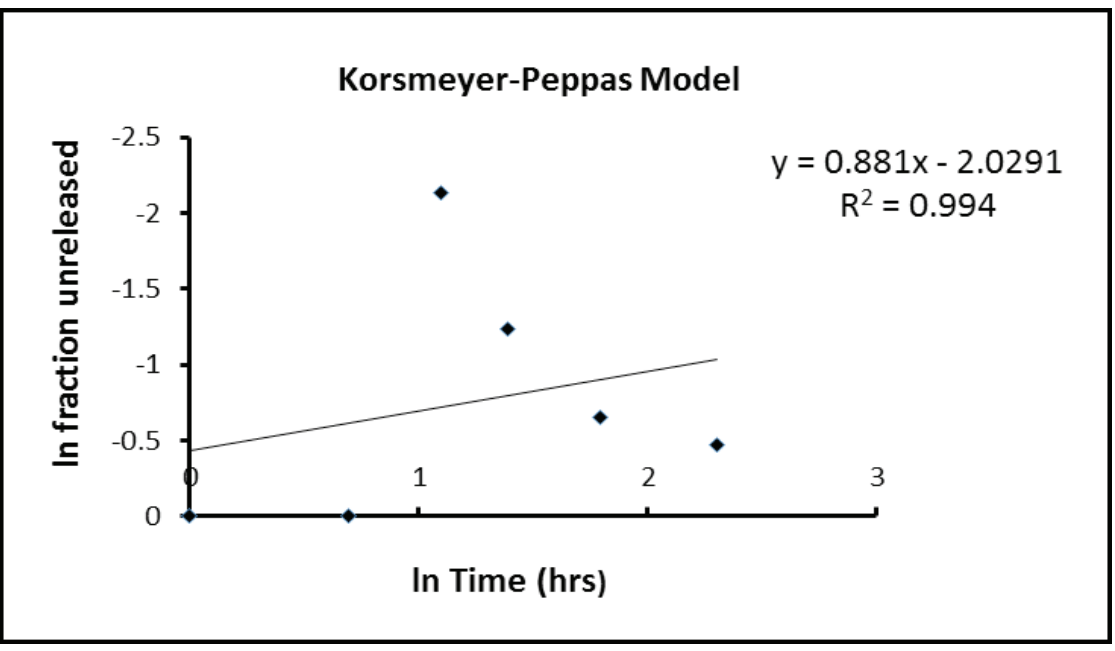

Figure 4. Graph of Korsmeyer-Peppas Model for formulation T-02

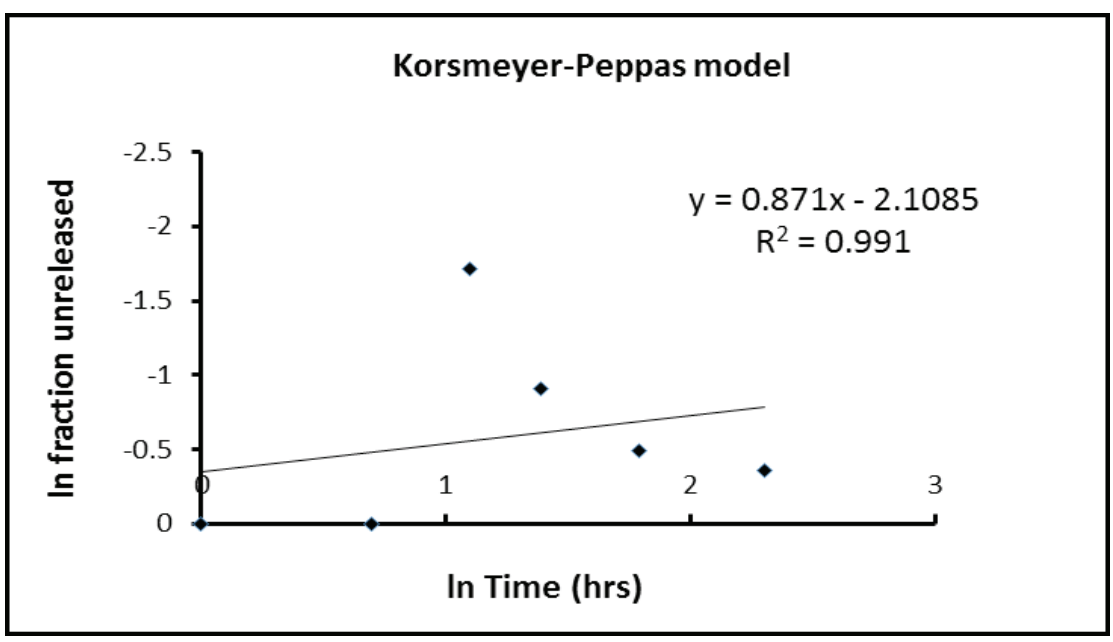

Figure 5. Graph of Korsmeyer-Peppas Model for formulation T-03 


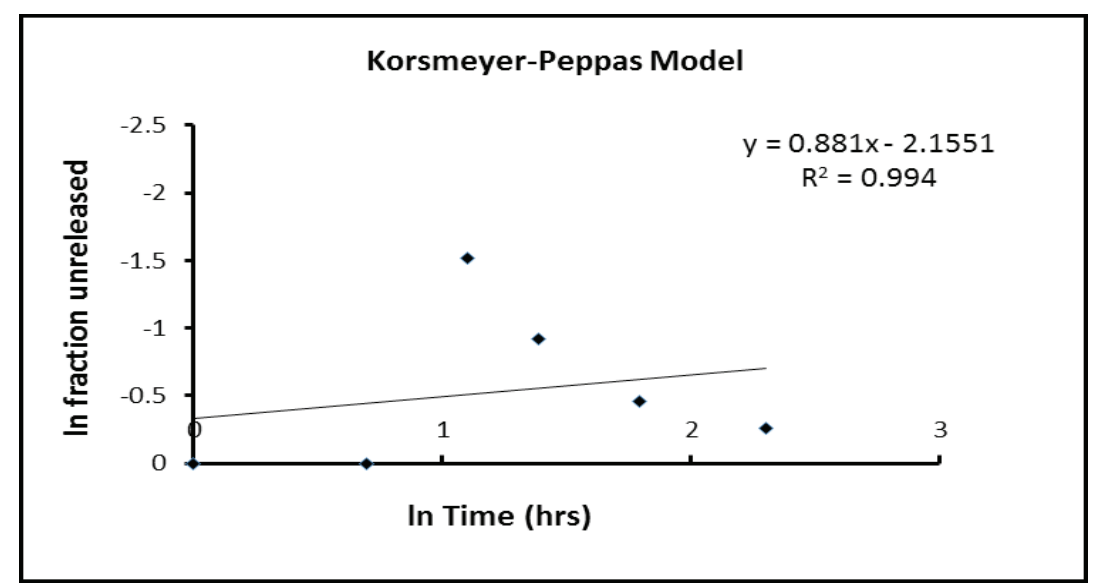

Figure 6. Graph of Korsmeyer-Peppas Model for formulation T-04

\section{DISCUSSION}

Orally administered dosage forms are designed in such a way to release most of their drug in the segment of GIT from which maximum absorption of the incorporated drug takes place. On the other hand, salts of weakly acidic drugs are shown to have much higher dissolution profiles than from their free acidic forms. Diclofenac a phenylacetic acid derivative is available in the form of free acid as well as sodium and potassium salts. To date most of the marketed products of diclofenac are available as sodium or potassium salts as they show enhanced solubility profile than the free acid form. Typical dosage forms of diclofenac are available as delayed release (DR) or sustained release (SR) for the sodium salt and immediate release (IR) for the potassium salt claiming to have greater solubility in the stomach in situations when quick action is desired. The current work aimed to combine both technologies in a single dosage form by incorporating salts of diclofenac like potassium and sodium providing immediate and sustained release effect respectively. Diclofenac potassium is formulated as orodispersible layer to provide immediate release in the oral cavity while considering the susceptibility of diclofenac sodium to the gastric environment it is formulated as sustained release core to withstand the harsh environment of stomach. In recent years, an increased attention has been paid to formulating not only rapid disintegrating/ dissolving tablets but also to oral disintegrating tablets that are intended to disintegrate and dissolve in the mouth. Most of the studies focuses on the functional properties of these super-disintegrant and relating them to the disintegrating efficiency and release rate. The disruption of the tablet takes place either because of the swelling of these super-disintegrant or through capillary action increasing their volume by many folds. Sodium starch glycolate, the anionic sodium salt of carboxymethyl ether is used as super-disintegrant for orodispersible tablets (ODT) which is characterized by very short disintegration time. Its disintegrating efficiency depends on the source of starch from which it is synthesized (potato starch source with ideal disintegrating properties) as well as on the degree of crosslinking. The introduction of large hydrophilic carboxymethyl groups helps in disrupting the hydrogen bonding between the polymer allowing water to penetrate the molecule while the degree of crosslinking reduces the water-soluble portion of polymer and the viscosity of dispersion medium. The sodium starch glycolate used in current experiment exhibited ideal super-disintegrant properties allowing the tablet to disintegrate within a matter of seconds without the need of water. The concentration of super-disintegrant was found to have a significant effect on disintegration time which is evident from the result of formulation T-02 where the amount of Primogel ${ }^{\circ}$ is decreased to $20 \mathrm{mg} / \mathrm{tab}$ and the disintegration time is increased to $30 \mathrm{sec}$. while the reverse phenomenon was observed in formulation T-03. The gelling ability of HPMC in physiological salt fluids like simulated intestinal fluid affects the release of drug from the matrix. Moreover, from the in-vitro release data it was evident that hydroxypropyl methyl cellulose (HPMC K15) as release modifier could be a better choice to formulate sustained release tablets of diclofenac sodium. The results obtained for formulation T-04 are strictly according to USP which states that not less than $65 \%$ drug should be released after $10 \mathrm{~h}$. The polymer drug ratio was found to be an important parameter in retarding drug release from the matrices. Direct 
compression method was found to be an easy and efficient way of making fast disintegrating tablet while HPMC can be used successfully to formulate sustained release dosage form. Due to time constraint the current project could not be extended to the stability studies and in-vivo evaluation however these studies can be conducted in the future. This project will help patients in improving compliance because of the reduced dosing frequency, quick and prolonged onset of action and will open new avenues for researchers to extend this methodology to other drugs whose rapid action is required and are suitable for oral route.

\section{CONCLUSION}

The outer orodispersible layer of diclofenac potassium and sustained release inner core of diclofenac sodium in a single tablet was successfully formulated which was the primary objective of the research. The retarding effect on drug release was significantly associated with increasing the concentration of HPMC. The stability studies and Invivo evaluation of the tablets is thus recommended as future objective.

\section{ACKNOWLEDGEMENT}

Saffron Pharma Faisalabad Pakistan is highly acknowledged for their gift samples (diclofenac sodium and diclofenac potassium) as well as the manufacturing and characterization facilities availed to carry out the research work successfully.

\section{CONFLICT OF INTERESTS}

\author{
Declared None
}

Ağızda dağılan tabaka olarak diklofenak potasyum, geciktirilmiş salım çekirdeği olarak diklofenak sodyum içeren iki tabakalı tabletin formülasyonu ve değerlendirilmesi

ÖZ

Diklofenak, bir fenilasetik asit türevi olup uzun yıllardan beri antienfamatuvar ve analjezik bir ilaç olarak kullanılmaktadır ancak bu etken maddeden hareketle hemen salım için yükleme dozu içeren geciktirilmiş salım formülasyonunun hazırlanması istenmektedir. $\mathrm{Bu}$ çalışmanın amacı, ağızda dağılan tabaka olarak diklofenak potasyum, geciktirilmiş salım çekirdeği olarak diklofenak sodyum içeren iki tabakalı tabletlerin formülasyonu ve değerlendirilmesidir. Diklofenak sodyum içeren çekirdek yaş granülasyon yöntemi ile hazırlanırken ağızda dağılan dış tabaka direct basım yöntemiyle ve süper dağıtıcı olarak sodyum nişasta glikolat varlığında hazırlandı.
Toz karışımı hem basım öncesi hem de basım sonrası özellikleri açısından değerlendirildi. Toz karışımının ve tabletlerin fiziksel özelliklerinin zorunlu standartlarla uyumlu olduğu görüldü. Ağızda dağılan kısmın 30 saniyeden kısa bir sürede dağılarak yükleme dozu olan diklofenak potasyumu saldığı, çekirdek kısmının ise simule bağırsak sıvısında (pH 6.8), 10 saate kadar diklofenak sodyum salınımı sağladığı tespit edildi. Kinetik ile ilgili veriler incelendiğinde, tabletin non-fickian salım gösterdiği ve Korsmeyer-Peppas modeline uygun olduğu tespit edildi. Tek bir tablet içeriğinde, ağızda dağılan tabaka olarak diklofenak potasyum, geciktirilmiş salım çekirdeği olarak diklofenak sodyum içeren ve süper dağıtıcı olarak sodyum nişasta glikolat içeren tabletlerin formülasyonu başarıyla yapıldı.

Anahtar Kelimeler: Ağızda dağılan tablet, geciktirilmiş salım, diklofenak, direkt basım, iki tabakalı tablet

\section{REFERENCES}

1. Gwen M, Joseph RR. Sustained and Controlled-Release Drug Delivery Systems. In: Modern Pharmaceutics. Editors: Banker GS, Rhodes CT. Marcel Dekker Inc., New York. 1996, pp. 575587.

2. Nagaich U, Bharti C, Kumar Pal A, Neha Gulati N. diclofenac sodium loaded sustained release matrix tablet possessing natural and synthetic polymers: Formulation and in vitro characterization. Indian J Pharm Edu Res 2014; 48: 49-55.

3. Patel VF, Liu F, Brown MB. Advances in oral trans mucosal drug delivery. J Cont Drug Deliv 2011; 153: 106-16.

4. Bhushan SY, Sambhaji SP, Anant RP, Mahadik KR. New drug delivery system for elderly. Ind Drug 2003; 37: 312-8.

5. Behnke K, Sogaard J, Martin S, Bauml J, Ravindran AV, Agren $\mathrm{H}$. Mirtazapine orally disintegrating tablet versus sertraline: A prospective onset of action study. J Clin Psychopharmacol 2003; 23: 358-64.

6. Zalte HD, Saudagar RB. Review on sustained release matrix tablet. Int J Pharm Bio Sci 2013; 3: 17-29.

7. Patil HG, Tiwari RV, Repka MA, Singh KK. Formulation and development of orodispersible sustained release tablet of domperidone. Drug Dev Ind Pharm 2016; 42: 906-15.

8. Gan TJ. Diclofenac: an update on its mechanism of action and safety profile. Curr Med Res Opin 2010; 26: 1715-31.

9. Billa N, Yuen KH, Khader MA, Omar A. Gamma-scintigraphic study of the gastrointestinal transit and in vivo dissolution of 
a controlled release diclofenac sodium formulation in xanthan gum matrices. Int J Pharm 2000; 201: 109-20.

10. Soppimath KS, Kulkarni AR, Aminabhavi TM. Encapsulation of antihypertensive drugs in cellulose-based matrix microspheres: Characterization and release kinetics of microspheres and tableted microspheres. J Microencapsul 2001; 18: 397-409.

11. Sung KC, Nixon PR, Skoug JW, Roburt JT, Gao P, Topp EM, Patel MV. Effects of formulation variables on drug and polymer release from HPMC based matrix tablets. Int J Pharm 1996; 142: 53-60.

12. Shoaib MH, Tazeen J, Merchant HA, Yousuf RI. Evaluation of drug release kinetics from ibuprofen matrix tablets using HPMC. Pak J Pharm Sci 2006; 19: 119-24.

13. Velasco M, Ford JL, Rowe P, Rajabi-Siahboomi AR. Influence of drug: Hydroxypropyl methylcellulose ratio, drug and polymer particle size and compression force on the release of diclofenac sodium from HPMC matrices. J Control Release 1999; 57: 75-85.

14. Stewart AG, Grant DJW, Newton JM. The release of a model low-dose drug (riboflavine) from hard gelatin capsule formulations. J Pharm Pharmacol 1979; 31: 1-6.

15. Khan KA, Rooke DJ. Effect of disintegrant type upon the relationship between compressional pressure and dissolution efficiency. J Pharm Pharmacol 1976; 28: 633-6

16. Cid $\mathrm{E}$, Jaminet F. Influence of adjuvants on the dissolution rate and stability of acetylsalicylic acid in compressed tablets. J Pharm Belg 1971; 26: 38-48.

17. Addnan Abdullah MD, Bepary S, Shamsur Rouf AS. In vitro dissolution studies of different brands of sustained release diclofenac sodium matrix tablet available in Bangladesh. Pak J Pharm Sci 2008; 21: 70-8.

18. Chickpetty SM, Raga B, Nanjwade BK. Studies on development of novel combined time and $\mathrm{pH}$ dependent solventless compression coated delivery systems for colonic delivery of diclofenac sodium. Asian J Pharm Clin Res 2010; 32: 110-3.

19. Gohel MC, Parikh RK, Nagori SA, Jethwa BA. Fabrication and evaluation of bi-layer tablet containing conventional paracetamol and modified release diclofenac sodium. Indian J Pharm Sci 2010; 72: 191-6.

20. Mutalik S, Naha A, Usha AN, Ranjith AK, Musmade P, Manoj K, Anju P, Prasanna S. Preparation, in-vitro, preclinical and clinical evaluations of once daily sustained release tablets of aceclofenac. Arch Pharm Res 2007; 30: 222-34.

21. Xu GJ, Sunada H. Influence of formulation changes on drug release kinetics. Chem Pharm Bull 1995; 43: 438-87.

22. Singla AK, Medirata DK. Influence of sodium lauryl sulphate on indomethacin release pattern. Drug Dev Ind Pharm 1988; 14: 1883-8.

23. Higuchi T. Mechanism of rate of sustained action medication. J Pharm Sci 1963; 52: 1145-9.

24. Hixson AW, Crowell JH. Dependence of reaction velocity upon surface and agitation (I) theoretical consideration. Ind Eng Chem 1931; 23: 923-31.

25. Korsmeyer RW, von Meerwall E and Peppas NA. Solute and penetrant diffusion in swellable polymers. II. Verification of theoretical models. J Polym Sci Polym Phys Ed 1986; 24: 40934.

26. Murtaza G, Ahmad M, Shahnaz G. Microencapsulation of diclofenac sodium by nonsolvent addition technique. Trop J Pharm Res 2010; 9: 187-95.

27. The United States Pharmacopeia; The United States Pharmacopeial Convention: Twinbrook parkway, Rockville. 2009.

28. Kramar A, TurkS, Vrečer F. Statistical optimisation of diclofenac sustained release pellets coated with polymethacrylic films. Int J Pharm 2003; 256: 43-52. 